\title{
epiphany
}

Journal of the Faculty of Arts and Social Sciences

International University of Sarajevo

ISSN 1840-3719/ No. 2

Spring 2009

\section{EU Enlargement and the Case of Bosnia and Herzegovina1: A Brief Historical Sketch}

\author{
Dzevada Šuško \\ International University of Sarajevo
}

\section{Introduction}

Whenever Bosnia and Herzegovina's political issues are discussed, the starting point is the Dayton Peace Agreement signed in December 1995 (Chandler; Bieber 2006). However, already in May 1992 with the beginning of the aggression, Bosnia and Herzegovina applied for a special guest status at the European Council aiming to prevent human rights abuses as a result of war. During the first months of the aggression it became obvious that the Bosniaks were systematically executed, expelled and brought to concentration camps. Yet, guest status to Bosnia and Herzegovina was not given until January 1994. Finally in April 2002 Bosnia and Herzegovina was accepted with full membership to the European Council (Solioz 2006 98). Nonetheless, the Dayton Peace Agreement is often seen as the milestone for the relationship between the European Union (EU) and Bosnia and Herzegovina.

Besides the Presidency of the EU and the European Commission, some EU countries such as France, Germany, Italy and United Kingdom were already involved in the Dayton Peace Agreement and the subsequent creation of the Peace Implementation Council (PIC). ${ }^{2}$ Dealing with the high number of Bosnian refugees in EU countries and bringing political stability in the EU region were

\footnotetext{
${ }^{1}$ I would like to thank Dr. Ali Gunes and Mustafa Bal for kindly supporting me in publishing this article. Furthermore, I am thankful to Dr.Mirsad Karić and Dr.Muhidin Mulalić who reviewed the manuscript and offered constructive comments.

2 The PIC represents 55 countries and agencies that were involved in the Dayton Peace Agreement in order to give financial support, provide troops or run directly operations in $\mathrm{BiH}$. The London Conference nominated Canada, France, Germany, Italy, Japan, Russia, United Kingdom, United States, the Presidency of the European Union, the European Commission and the Organization of the Islamic Conference represented by Turkey (OHR General Information).
} 
surely the PIC's main goals (for Germany's insisting on the question of return in Dayton see Bendiek 2004, 89). Since the Dayton Peace Agreement is designed to "end a war not to build a state", as the former OHR High Representative Lord Paddy Ashdown (15) contended, it is obviously now the task of the EU 'to build a state' with solid and stable institutions. This means that the economic, political, juridical and civil transition of Bosnia and Herzegovina from communism, aggression, ethnic cleansing and genocide to a democratic peaceful state is closely linked with its adaptability to be a part of the EU.

This process evokes usually a variety of questions: Are Bosnian state institutions EU-adaptable? What are the main obstacles? How much time will take a full membership to the EU? What advantages and disadvantages will Bosnia and Herzegovina have with EU membership?

The resources used for this research paper originate to a great part from the internet, starting with documents from the websites of the international community: OHR-Office of the High Representative in Sarajevo, European Union, Council of the European Union, European Commission in Brussels and in Sarajevo as well as the Bosnian Directorate for European Integration (DEI). Few Bosnian authors explicitly deal with Bosnia and Herzegovina and the EU, such as Nerzuk Ćurak, Nikola Kovač, Mirko Pejanović and Emir Hadžikadunić. As far as nonBosnian authors are concerned, Florian Bieber, Solveig Richter, Marie-Janine Calic, Christophe Solioz, Robert Belloni, Bruno Sergi and Qerim Qerimi as well as Graham Timmins and Dejan Jovic delivered relevant contributions. David Chandler, though, gives a critical analysis of post-Dayton Bosnia including its approach to the EU. Whereas Chandler advocates a less interventionist approach by the international community to stabilize democracy other scholars like Richter and Calic tend more to the view that the lack of consensus among the political elites in Bosnia and Herzegovina requires a rather strong hand from outside to impose the needed constitutional changes in Bosnia and Herzegovina and hence to clear the path for the EU. As soon as a feasible constitution is set, then the state system of Bosnia and Herzegovina has a real chance to start functioning properly. 
This research analysis will offer mainly a historical overview of the relations between the European Union and Bosnia and Herzegovina. Furthermore some reconsiderations regarding the above mentioned meta- questions of the process are given.

\section{A Prelude to Membership}

As far as the EU in general is concerned, there are three main bodies that decide on the enlargement strategy of the EU and thus about the membership of Bosnia and Herzegovina. They include the European Commission representing common EU interests, the European Parliament representing the people of Europe, and the Council of the European Union representing national governments. Although, the views of individual member states towards the integration of Bosnia and Herzegovina differ to great extent ${ }^{3}$.

The openness to integrate Bosnia and Herzegovina to the EU is confirmed in June 1998 with the "Declaration on Special Relations between EU and BiH"4. Thus the primary condition is fulfilled. In terms of membership conditions, the 1992 Treaty on European Union signed in Maastricht, Article 6, says that any European state which respects the principles of liberty, democracy, human rights, fundamental freedoms and the rule of law qualifies for EU membership. Furthermore, the Copenhagen meeting in 1993 added requirements which new members must have achieved before entering the EU. Hence, these Copenhagen criteria include: stable institutions guaranteeing democracy, the rule of law, human rights and respect for and protection of minorities; a functioning market economy and the capacity to cope with competitive pressure and market forces

\footnotetext{
3 This issue cannot be discussed in detail at this point. A critical assessment of British foreign policy in the region was provided by Brendan Simms' Unfinest Hour. Britain and the destruction of Bosnia, (London: Penguin 2002); for a comparative perspective stressing also differences within the countries Brian C. Rathbun's Partisan interventions: European party politics and peace enforcement in the Balkans, (Ithaca et al.: Cornell University Press 2004).

${ }^{4}$ In comparison to Turkey the EU is reluctant in accepting Turkey as a partly Asian state. The openness to integrate $\mathrm{BiH}$ to the EU is confirmed in June 1998 with the "Declaration on Special Relations between the EU and BiH".
} 
within the Union; the ability to take on the obligations of membership, including support for the aims of the political, economic and monetary union; furthermore a public administration capable of applying and managing EU laws in practice as it was underlined by the Madrid European Council in 1995 (European Council in Copenhagen. Conclusions of the Presidency).

\section{5-1999 Extension of powers of PIC High Representative}

Bosnia and Herzegovina is a special case: since World War II genocide and concentration camps experienced a repeat on European soil. According to the report "Repairing reconstructing reconnecting" from 1998, the EU had to deal with 750.000 refugees from war zones while 1.2 million citizens had to flee abroad. After signing of the Dayton Peace Agreement, Bosnia and Herzegovina had to deal with a complete devastation of the infrastructure, high unemployment, displaced people, and a ruined economy. These conditions seriously threatened the region's stability. Consequently, the EU committed itself with donations to reconstruct Bosnia and Herzegovina, to provide democracy and a viable market economy. The first parliamentary elections held in 1996 were seen as the first step towards democracy building in Bosnia and Herzegovina. Since then, four more parliamentary and presidential elections have been held (1998, 2000, 2002, 2006; Bieber 2008). Apart from the DPA -architecture, the EU and EC have become strong partners with Bosnia and Herzegovina and cooperate intensely with the Office of the High Representative (OHR), United Nations (UN), UN High Commissioner for Refugees (UNHCR), the NATO Stabilization Forces (SFOR) and the Organization for Security and Co-operation in Europe (OSCE). EU governments even insisted that the Office of the High Representative should be run by a European representative (Cousens and Cater 46). Chandler states that the DPA was made so flexible that it has in fact facilitated external regulation rather than restricting it. DPA, as Chandler continues, thus enabled international actors to shape and reshape the agenda of post-war transition: 
Dayton's flexibility has been the key actor enabling external powers to permanently postpone any transition to Bosnian 'ownership'. The only transition which has taken place has been from the ad hoc policyownership of self-selected members of the Peace Implementation Council (PIC) to direct regulatory control under the aegis of the European Union (EU). (Chandler 30)

During the first period, 1995-1999, PIC extended the powers of the High Representative but with little clear policy direction or end point for the ad hoc international administration. PIC was established to provide international legitimacy in absence of UN involvement and to include EU and cohere international management in the Dayton process. Several PIC meetings such as in Florence (June 1996), Paris (November 1996), Sintra (May 1997), and Bonn (December 1997) enabled PIC to rewrite its own powers and those of the High Representative (OHR). For example, it was decided at the Sintra meeting that obstructive Bosnia and Herzegovina representatives may receive visa restrictions on travel abroad, and any media network or programme which was counterproductive to DPA may be suspended (PIC Sintra Declaration). The socalled "Bonn powers" are until today often mentioned, especially in everyday politics because the High Representative was since then empowered to impose legislation giving international officials executive and legislative control over Bosnia and Herzegovina (PIC Bonn Conclusions). This included the dismissal of elected representatives and government officials who obstruct the implementation the DPA. From 1998 to 2005, following the webpage of the Office of the High Representative (www.ohr.int), there were in total 117 officials which were removed by the High Representative from their respective posts, out of which were 48 Serbs, 45 Croats and 24 Bosniaks. Therefore by 1999 the PIC and OHR had accumulated an array of powers, particularly the Bonn powers, unforeseen in 1995 when Dayton Agreement was signed.

On the other hand there are disputes and severe doubts on the PDA"constitution" which was designed most of all "to end a war" and is not yet 
functioning properly in respect of Bosnia and Herzegovina's future as a member state of the European Union. The ethnic division of the country even among the youth is deeper than ever before and confirms these doubts. Kasim Trnka, a jurist and legal scientist, stated that for the past 12 years after the war 279 laws were passed. Additionally, 112 laws were imposed by the High Representative. Furthermore, 260 bills were discussed in parliament and were not passed. 136 bills were not approved by the House of Representatives due to entity voting. Out of these 136 bills, 20 bills were vetoed by entity voting in Federation and the left 116 bills were vetoed by entity voting in Republika Srpska (TV debate on BHT1 in December 2008). Interestingly, the main objective of the House of Peoples (Upper House) is to protect vital national interests. However, only four times since the first establishment of Parliament in 1996 constituent peoples have used veto in House of Peoples and stopped passing the law. No one of these has been used by Serbs - because the Serb national interest can be protected in the House of Representatives which is supposed to promote and protect individual rights and not national interest of one ethnic group. Consequently, many political actors have realized that there is urgent need for constitutional changes. And this has even been said by the Parliament of the European Council in 2007:

For the international community, the adoption early on in the new legislature of the already agreed constitutional amendments remains as the precondition for any serious attempts to embark into the more far-reaching reforms which are necessary to consolidate the statehood of $\mathrm{BiH}$ and its full integration in European and Transatlantic structures. (Council of Europe. Information Documents SG/Inf(2006)16final 7 February 2007)

The "Regional Approach" in 1997 established political and economic conditionality for the development of bilateral relations between Bosnia and Herzegovina and the EU, in terms of trade, financial assistance and economic cooperation. Bosnia and Herzegovina's official approximation towards the 
membership of the EU, though, started on 8 June 1998. At the Luxemburg Council the Declaration on Special Relations between the EU and Bosnia and Herzegovina was adopted and the EU/BiH Consultative Task Force (CTF) established. The aim was increasing cooperation and assisting in policy-making in the crucial fields of judicial reform, education, media, good governance and economic reform (PIC Luxembourg Declaration). Nonetheless, Chandler states: "However, despite an increasingly direct EU input into policy-making, the EU played a subordinate and supporting role within PIC Dayton framework rather than dictating its own terms" (Chandler 35). Still the DPA was of major importance and the impact of the EU was more on civilian level then.

After the NATO intervention in Kosovo (March 1999) new approaches for stabilizing the whole region were required. They were drafted in the Stability Pact for South-Eastern Europe, which was agreed in Cologne on 10 June 1999 between the states of South-Eastern Europe, the EU, the US and Russia (http://www.stabilitypact.org/about/constituent.asp). The idea was to link improvement of intraregional cooperation between the countries, with the perspective of membership to the European Union - accompanied by political and economic conditionality. In the following years the most effective instrument became the Stabilisation and Association Process (SAP), which should via a subsequent Stabilisation and Association Agreement (SAA) finally pave the way for all the countries to full membership. With this perspective and the financial assistance of the CARDS Programme, from 2000 on the influence of the EU in the region became increasingly greater.

\section{0-2007 Transformation of external regulative mechanisms}

This period saw within the post-Dayton process a gradual transformation of external regulative mechanisms to Bosnian ownership under the leadership of the EU. Thereby mechanisms of regulation shifted informally from the PIC to the $\mathrm{EU}$, and Dayton became subordinate to the requirements for an eventual EU membership. 
The Road Map announced in March 2000 by EU Commissioner Chris Patten was a first step for Bosnia and Herzegovina in the Stabilization and Association Process (SAP). This document contained 18 conditions which Bosnia and Herzegovina had to fulfil beginning with the preparation of a Feasibility Study which would set the framework for the Stabilization and Association Agreement (SAA). These conditions were related to elections, civil service, state institutions, border services, judiciary, trade regulations, foreign direct investment, property laws and public broadcasting.

The shift from DPA to EU accession was constantly confirmed on summits and meetings. In June 2000, the Feira European Council declared all SouthEastern European countries as "potential candidates" for EU membership. The Zagreb Summit in November 2000 introduced a Community programme of Assistance for Reconstruction, Development and Stabilization (CARDS) and a programme of EU technical assistance for Bosnia and Herzegovina (Final Declaration). The CARDS programme supported Bosnia and Herzegovina with $€$ 240 million (Chandler: 36) focusing on public administration reform (customs and taxation), justice and home-affairs (police reform, border management, judicial reform) and investment climate (trade, education, environment, infrastructure). Furthermore, in 2001 the European Commission adopted a Country Strategy for Bosnia and Herzegovina for the period of 2002-2006. In November 2000, an autonomous preferential customs regime between EU and Bosnia and Herzegovina was adopted allowing products from Bosnia and Herzegovina to enter EU duty free. However, statistics of the Foreign Trade Chamber of Bosnia and Herzegovina shows that this policy has increased trade deficit in favour of EU and at the cost of Bosnia and Herzegovina and its citizens (Pregled uvoza i izvoza BiH-EU 2000-2007).

The gradual transfer of power from the PIC to the EU became more evident in OHR's 2002 reform when joint actions were adopted for the appointment of an EU Special Representative and the launching of the EU Police Mission (EUPM). Thus, OHR Lord Paddy Ashdown (2002-2006) became the first EU Special 
Representative and simultaneously the High Representative. A Board of Principles was established chaired by the EU Special Representative as a weekly meeting in Sarajevo to coordinate the activities of the OHR with SFOR, OSCE, EUPM, UNHCR, EC, World Bank, IMF and UNDP. OHR's growing dependence on the EU is also indicated by the OHR's financial contributors. In the current term (2008/09) EU provides 53\%. Further contributions stem from USA (22\%), Japan (10\%), Russia (4\%), Canada (3\%) and the Organisation of Islamic Conference (OIC, 2,5\%). However, the OIC does not seem to have any visible influence on decision-making process (Office of the High Representative. General Information).

Within Bosnia and Herzegovina, the eight month rotation of the Chairman of Council of Ministers (CoM) was abolished after the elections in 2002. Since then the CoM remained for the whole legislative period (the first was Adnan Terzić, 2002-2007), adopting a high level of executive authority and becoming de facto Bosnia and Herzegovina's prime minister. This was important because CoM's task was besides coordinating strategies and policies among state institutions, ensuring harmonization Bosnia and Herzegovina's laws with the acquis communautaire of the EU. In April 2002, Bosnia and Herzegovina was accepted to the European Council and adopted the European Convention on Human Rights. In September that year the "Road Map" was adopted as "substantially completed" by the European Commission. Soon the Directorate for European Integrations (DEI), founded in early 2003, has become the main partner to the EC in the Stabilization and Association Process. DEI has been tasked with negotiating and supervising the implementation of further agreements made with the EU, especially the Feasibility Study, which should estimate its capacity to implement the SAA during 2003. On the Thessalonica Summit in June 2003 the EU committed itself to integrate countries from the Western Balkans presenting additional instruments to enhance EU regulation. The most important tool were the new "European Partnerships" made to strengthen the SAP (Chandler: 36-38). 
On the basis of the results of the Feasibility Study presented in November 2003 as the "Report from the Commission to the Council on the preparedness of Bosnia and Herzegovina to negotiate a Stabilization and Association Agreement with the European Union", the EU decided in June 2004 for a first "European Partnership" with Bosnia and Herzegovina to define the country's political, economic and other priorities preparing SAA negotiations. The Bosnian government was expected to respond to this Partnership by working out and implementing action plans with a timetable and details of how they intend to address the Partnership's priorities. Particularly, the intensity of EU engagement in Bosnia and Herzegovina necessitated the reinforcement of (a) meetings of EU/BiH Consultative Task Force to assist in Annual Reports and annual Action Plans (established already in 1998) and (b) the Coordination Board for Economic Development and EU Integration as the main steering body between the central government and the entities.

The same year, the Parliamentary Assembly of the Council of Europe reviewed the quality of Bosnia and Herzegovina's democracy. It demanded the strengthening of central state institutions and questioned the extent to which the current role of the High Representative is compatible with the membership of Bosnia and Herzegovina in the Council of Europe ("Strengthening of democratic institutions in Bosnia and Herzegovina"). A further step toward the empowerment of the EU was the replacement of NATO's SFOR with EUFOR (Althea operation) in December 2004 which meant the end of the UN International Police Task Force (IPTF) (Chandler 39).

The negotiations on SAA between Bosnia and Herzegovina and EU were officially opened on 25 November 2005 in Sarajevo. The main stakeholders in negotiations were the Directorate General for Enlargement of the European Commission headed by Olli Rehn and the DEI, the negotiating team of Bosnia and Herzegovina, under the leadership of Osman Topčagić. Bosnia and Herzegovina's domestic problems which are visible through a lack of consensus among the elected political elites who represent the three constituent peoples of the country 
lead to a lack of progress in implementing necessary reforms. Thus it took two years to conclude the negotiations on SAA. New instruments of monitoring, consultation and steering had to be defined. In 2006, the Consultative Task Force (CTF) was re-named Reform Process Monitoring (RPM) to mark the start of a new phase in EU-BiH relations, the start of negotiations of a SAA. A year later the CARDS programme was replaced by the Instrument of Pre-Accession (IPA) which focuses on institution building and socio-economic development. In the end of 2007, the Bosnia and Herzegovina Progress Report was made including the Council Enlargement Strategy and Main Challenges 2007-2008.

\section{First serious step to EU: SAA}

The informal process of EU regulation became a contractual one when Bosnia and Herzegovina initialled the Stabilization and Association Agreement (SAA) on 4 December 2007. The meaning of that step was then pointed out by Dimitris Kourkoulas, Head of Delegation of the European Commission to Bosnia and Herzegovina: "The SAA is the first step in the EU integration process. It confirms that the prospect of EU membership is open for BiH" (TV Debate $13 \mathrm{Dec}$ 2007). For the implementation of the agreement the European Commission required progress in six key priorities which are (1) ICTY cooperation, (2) police reform, (3) establishment of a public self-sustainable broadcaster, (4) public administration reform, (5) uniting the entities' economies to a single economic space, and (6) providing conditions for the work of all institutions in terms of financing, personnel, equipment.

After having been signed on 14 June 2008, the agreement becomes enforceable when it has been ratified by the Bosnian government, European Parliament and the national parliaments of EU members. The adoption of the SAA in the Bosnian State Parliament was a prerequisite for its ratification in EU countries. In October 2008, the Bosnian State Parliament's House of Representatives and the House of Peoples gave their consent for ratification of 
the SAA. Under the Bosnian Constitution, SAA had still to be ratified by the Bosnian State Presidency as well.

The SAA is an international agreement entailing mutual rights and obligations that has precedence over any other law of the country and is seen as starting point for further constitutional amendments which are necessary for the future normal functioning of the country. The EU Special Representative and the executive policy-making institution of the Directorate of European Integration maintain full regulatory control over the SAP. For the coming period of 2007 to 2009 the Multi-annual Indicative Planning Document (MIDP) provided Bosnia and Herzegovina with $€ 226$ million in order to realize Bosnia and Herzegovina's development strategy to EU Integration.

Furthermore, the SAA, if properly implemented, is regarded as the first rung on the long path towards the membership of the 27-member bloc. Accordingly, Bosnia and Herzegovina has legal obligations in the fields of SAA within strict time limits. These necessary conditions are named in the 10 chapters of the SAA such as political dialogue, regional cooperation, free movements of goods, movement of workers, business plans, provision of services, capital, justice and home affairs. These chapters include 1.200 regulations and directives which must be gradually transposed from European legislation in order to meet the criteria for an EU membership.

The main advantages of the SAA to Bosnia and Herzegovina are credibility building among the international public, establishment of a free trade zone between Bosnia and Herzegovina and EU which should increase investments and employment, better efficiency of institutions, liberalization of a visa regime, and democratic-political as well as economic stability in general. Furthermore, the struggle against organised crime and corruption is a serious problem to be solved since the achievements of these objectives depend to a large part to the country's own political will to align with European standards and values.

\section{Bosnia and Herzegovina's adaptability to the European Union}


EU interests are strategic in terms of integrating South-Eastern European states in EU structure and global in terms of security and peace all over the European continent, as the International Commission on the Balkans stressed:

We should clearly bring the region into the EU. Rather we need to establish the sequence of policy steps to be undertaken and the structure of the incentives that will make them work. We need policies so that the region can get on, get in and catch up with the rest of Europe. (The Balkans in Europe's Future 9)

The EU is the main trade partner of Bosnia and Herzegovina as it is visible in the regularly updated statistics about Bosnia and Herzegovina and its bilateral trade with the EU and trade with the world. In 2007, imports coming from the EU made up $66.7 \%$ of total imports by Bosnia and Herzegovina, while exports to the EU accounted for $71.4 \%$ of its total exports. In the same year, EU imports from Bosnia and Herzegovina grew by $6.1 \%$ year on year to reach over 1.8 billion euros, while exports to Bosnia and Herzegovina grew by 8.3\%, reaching over 3 billion Euros. Exports go mainly to Italy, Germany and Slovenia and imports originate from these countries, and to some extent from Austria.

In terms of reforms toward the EU, Bosnia and Herzegovina's approach to the European Council needs to be included. According to Solioz, until February 2006, 51 treaties were signed and ratified, 21 treaties were just signed but not ratified yet, and there were still 129 treaties neither signed nor ratified. Several reports monitoring Bosnia and Herzegovina indicated problems with the implementation and with self-responsibility during the realization of reforms (Solioz 99-100). On the other hand, Topčagić claims that greatest progress has been made in the fields of border management, migration, asylum; internal affairs; judiciary through establishing the Court of Bosnia and Herzegovina, the High Judicial and Prosecutorial Council, the Prosecutor's office of Bosnia and Herzegovina; establishment of independent regulatory bodies such as the Regulatory Communications Agency (Bulja and Subasic 3). This progress was also 
confirmed by the European Commission in November 2007 (Enlargement Strategy and Main Challenges 2007-2008).

In Bosnia and Herzegovina there are still many internal obstacles and challenges to face. The police reform was finally achieved (Richter), but the constitutional reform in today's perspective decides the fate of the present twoentity structure. While the Bosniak politicians consider the Republika Srpska a genocidal creation, Serb politicians threaten with secession from Bosnia and Herzegovina and Croats ask for a tripartite Bosnia and Herzegovina where every constituent people has its own federal unit (Loza 1-4). This implies that there is a need of a stronger intervention from the EU with a clear vision of Bosnia and Herzegovina's state configuration when it comes to the constitutional changes. The Bosnian constitution set up by the Dayton Peace Agreement established a "complicated, non-efficient and expensive state" as Srđan Dizdarević contends (90).

Whereas usually other states spend about $14-16 \%$ of the budget for the administration, Bosnia and Herzegovina spends $60 \%$ of the GDP for its heavy administration which has 14 governments and 180 ministers (Dizdarević 90). No doubt that this dysfunctional system must be radically changed. The constitution is to begin with, it is actually the main obstacle within Bosnia and Herzegovina for the development of stable, transparent and efficient democratic institutions. The constitutional reform was planned after the local elections are held in October 2008. As soon as the constitution gets successfully changed to the benefit of a sovereign state of Bosnia and Herzegovina, the adaptability to EU standards is no more questionable.

\section{Conclusion and Perspectives}

The European Union is routinely involved in every aspect of Bosnia and Herzegovina. This is also the main critique for the transition work does not go towards Bosnian ownership. On the other hand, Bosnia and Herzegovina such as all the other former communist countries from East and South-East Europe 
experienced what it means to live in the world of borders, thinking barriers, prohibitions. Therefore the citizens of these countries expect from the EU opening up of societies, elimination of all kinds of barriers and obstacles to free and unconstrained exchange of ideas, of people, of goods and services, and of money. Furthermore with the EU and investments from outside Bosnian citizens expect economic prosperity and more employment which should reduce the number of youth exodus. Citizens also expect political stability and political consensus of governing political powers about character and development of the country which will make the return of displaced persons easier and reduce nationalist rhetoric to a preference of civil values.

Bosnia and Herzegovina has still to fulfil several conditions, which are strategic and institutional, in order to enter EU. Strategic conditions are a stable peace, defence of human rights on European standards ${ }^{5}$, economic renewal, return of refugees and displaced persons ${ }^{6}$, social transition, building democratic institutions whereas institutional conditions include a modern and efficient state of Bosnia and Herzegovina. Of strategic importance is the membership in NATO's program "Partnership for Peace" in December 2006 which aimed to increase peace and security in Bosnia and Herzegovina and decrease national and secessionist tensions. The integration into NATO makes a final integration to EU more secure. Basically, when talking about integration, it can be concluded that integration occurs on three levels: (1) Internal - political, economical, and cultural; (2) Regional - Pact of Stability of South-Eastern Europe and (3) European- integration to the EU (Pejanović 159).

When it comes to EU, Timmins and Jović (1) note that:

Although the EU has aspirations to develop a military dimension to its external identity, its international presence continues to be articulated predominantly through soft power, for example, diplomatic, economic

\footnotetext{
${ }^{5}$ An extended elaboration of human rights in the EU and BiH can be seen at Sadiković (197-206).

${ }^{6}$ Pejanović argues that it will take 50 more years to realize the return of all displaced people according to the actual dynamics (2005 160).
} 
and normative foreign policy instruments. The next wave of EU enlargement ... therefore represents a crucial contribution both to the continued creation of a stable European order and the credibility of the EU as an effective international actor.

Furthermore, there are indications that $\mathrm{EU}$ is suffering from an enlargement fatigue after the mammoth enlargement in 2004. Hence, next to Bosnia and Herzegovina's internal obstacles, there might be not sufficient will to enable the necessary institutional and financial reform that would allow the EU to continue to expand its membership (Timmins and Jovic 3). Nonetheless even before 2004, the European Council and the European Commission should have emphasized more the political dimensions of state-building in Bosnia and Herzegovina instead of paying too much attention to technical and administrative aspects (Solioz 107).

\section{Works Cited}

Ashdown, Lord Paddy. "International Humanitarian Law, Justice and Reconciliation in a Changing World." The Eighth Houser Lecture on International Humanitarian Law. New York, 3 March 2004. 10 Nov 2008. www.nyuhr.org/docs/lordpaddyashdown.pdf.

Belloni, Robert. State Building and International Intervention in Bosnia. London: Routledge, 2007.

Bendiek, Annegret. Der Konflikt im ehemaligen Jugoslawien und die europäische Integration. Eine Analyse ausgewählter Politikfelder. Wiesbaden: VS-Verlag 2004.

---. "The EU in South East Europe." The Boundaries of EU Enlargement. Finding a Place for Neighbours. Ed. Joan DeBardeleben. Houndmills: Machmillan 2008. pp. 222-237

Bieber, Florian. "After Dayton, Dayton? The Evolution of an Unpopular Peace." Ethnopolitics, 1 (2006): 28-30.

---. Bosna i Hercegovina poslije rata: politički sistem u podijeljenom društvu. Sarajevo: Buybook, 2008.

Blockmans, Steven. Tough Love: The European Union's Relations with the Western Balkans. The Hague: T.M.C. Asser Press, 2007. 
Bosnia and Herzegovina Council of Ministers. EU Integration Strategy of Bosnia and Herzegovina. No place and no date. 10 Nov 2008 www.dei.gov.ba/en/.

"Bosnia and Herzegovina and controversies of the EU integration process." Ed. Fondacija Heinrich Böll, Ured za Bosnu i Hercegovinu. Sarajevo, 2008.

Bosnia and Herzegovina. EU Bilateral Trade and Trade with the World. 10 Sept 2008. 14 Nov 2008 http://trade.ec.europa.eu/doclib/docs/2006/september/tradoc_113358.pdf

Bulja, Amela, and Armela Subašić. “Bosnia: Stable Mates.” Transitions Online 08.04.2008.

Calic, Marie-Janine. “The Western Balkans on the Road Towards European Integration." (2005) 10 March 2009 http://library.fes.de/pdf-files/id/03273.pdf

Chandler, David, ed. Peace Without Politics? Ten Years of International State-Building in Bosnia. London and New York, 2006.

CIA The World Factbook. Bosnia and Herzegovina.10 Nov 2008 https://www.cia.gov/library/publications/the-world-factbook/geos/bk.html

Commission of the European Communities. Communication from the Commission to the Council and the European Parliament. The Western Balkans and European Integration. Brussels, 21.5.2003.

---. Enlargement Strategy and Main Challenges 2007-2008. Brussels, 6.11.2007. 10 Nov 2008. www.dei.gov.ba/en/?ID=387.

Commission staff working document Bosnia and Herzegovina 2007 Progress Report accompanying the Communication from the Commission to the European Parliament and the Council Enlargement Strategy and Main Challenges 2007 2008. 14 Nov 2008. http://eur lex.europa.eu/LexUriServ/LexUriServ.do?uri=CELEX:52007SC1430:EN:HTML.

"Council Decision of 14 June 2004 on the principles, priorities and conditions contained in the European Partnership with Bosnia and Herzegovina (2004/515/EC) http://eurlex.europa.eu/smartapi/cgi/sga_doc?smartapi!celexplus!prod!DocNumber\&lg= n\&type_doc=Decision\&an_doc $=2004 \&$ nu_doc $=515$

"Council Decision of 18 February 2008 on the principles, priorities and conditions contained in the European Partnership with Bosnia and Herzegovina and repealing Decision 2006/55/EC". Official Journal of the European Union 19.3.2008. 14 Nov 2008. www.dei.gov.ba/en/?ID=419.

Council of Europe. Bosnia and Herzegovina: Compliance with obligations and commitments and implementation of the post-accession co-operation programme. Update on developments (July - December 2006). Document 
presented by the Secretary General. Information Documents SG/Inf(2006)16final 7 February 2007. 17 March 2009

https://wcd.coe.int/ViewDoc.jsp?id=1080039\&BackColorInternet=9999CC\&Ba

kColorIntranet=FFBB55\&BackColorLogged=FFAC75

---. Parliamentary Assembly. Strengthening of democratic Institutions in

Bosnia and Herzegovina. Resolution 1384 (2004). 02 Dec 2008 http://assembly.coe.int/main.asp?Link=/documents/adoptedtext/ta04/eres13 4.htm

Cousens, E. and C.Cater. Towards Peace in Bosnia: Implementing the Dayton Accords. Boulder, 2001.

Direkcija za evropske integracije BiH. Europuls. Bilten Direkcije za evropske integracije BiH. Sarajevo, December 2007.

---. Strategije integriranja Bosne i Hercegovine u Europsku uniju: nacrt / Vijeće Ministara Bosne i Hercegovine. Sarajevo, 2005.

Dizdarević, Srđan. "The Need to Change the Constitution of Bosnia and Herzegovina." Südosteuropa Mitteilungen. 04-05 (2005): 90-93.

Džihić, Vedran et al. Europa-verflucht begehrt. Europa-Vorstellungen in BosnienHerzegowina, Kroatien und Serbien. Wien: Braumüller, 2007.

Europa. Panorama of the European Union. 10 Nov 2008 http://europa.eu/abc/panorama/index_en.htm.

---. Overviews of the European Union enlargement activities. 10 Nov 2008 http://europa.eu/pol/enlarg/print_overview_en.htm

European Commission. Commission Staff Working Paper: Bosnia and Herzegovina Stabilization and Association Report 2004. Brussels, no date.

---. Bosnia and Herzegovina Country Strategy Paper 2002-2006. 10 Nov 2008 http://ec.europa.eu/enlargement/pdf/financial_assistance/cards/publications/b osnia_country_strategy_en.pdf.

---. Report from the Commission to the Council on the preparedness of Bosnia and Herzegovina to negotiate a Stabilization and Association Agreement with the European Union, COM (2003) 692 final, Brussels, 18 November 2003.

---. Enlargement. Bosnia and Herzegovina - Relations with the EU. 10 Nov 2008 http://ec.europa.eu/enlargement/potential-candidatecountries/bosnia_and_herzegovina/eu_bosnia_and_herzegovina_relations_en.htm

European Council in Copenhagen. Conclusions of the Presidency. 21-22 June 1993. 10 Nov. 2008 http://ue.eu.int/ueDocs/cms_Data/docs/pressdata/en/ec/72921.pdf. 
Gruppe, Claudia and Kušić, Siniša. The Western Balkans on Their Way to the EU?. Frankfurt/Main: Peter Lang, 2007.

Hadžikadunić, Emir. Od Dejtona do Brisela. Sarajevo: ACIPS, 2005.

International Commission on the Balkans. The Balkans in Europe's Future. Sofia, 2005.

Karić, Mirsad. Political System of Bosnia and Herzegovina, 1995-2005: Power-Sharing in Theory and Practice. Diss. IIU Malaysia, 2007.

Kourkoulas, Dimitris. “Cetiri uvjeta za BiH.” Europuls. Bilten Direkcije za evropske integracije BiH (ed). Sarajevo, December 2007.

---. TV debate. Kako u Evropu. BHT1 14 Dec 2007.10 Nov 2008. http://www.delbih.ec.europa.eu/?akcija=vijesti\&akcija2=pregled\&jezik=2\&ID= 60

Kovač, Nikola. "Političke Refleksije. Bosna i Hercegovina u svjetlu evropskih integracija." Duh Bosne. Međunarodni, interdisciplinarni, dvojezični, online časopis. 2 (April 2007):1-7.

Loza, Tihomir. “Bosnia: A Merry Dance”. Transitions Online. 18.03.2008: 1-4.

Office of the High Representative. General Information. 10 Nov 2008 www.ohr.int/ohrinfo/gen-info/\#pic.

---. PIC Luxembourg Declaration. Luxembourg, 9 June 1998. 10 Nov 2008 http://www.ohr.int/pic/default.asp?content_id=5188.

---. OHR BiH TV News Summary, 18 June 1998. 10 Nov 2008 http://www.ohr.int/ohrdept/presso/bh-media-rep/summaries-tv/obn/default.asp?content_id=1193.

---. PIC Bonn Conclusions. 10 Dec 1997. 10 Nov 2008 http://www.ohr.int/pic/default.asp?content_id=5182.

---. PIC Sintra Declaration. 30 May 1997. 10 Nov 2008 http://www.ohr.int/pic/default.asp?content_id=5180

---. Status, Staff and Funding of the OHR. 10 Nov 2008 www.ohr.int/ohr-info/gen info/\#pic

Ott, Andrea and Kirstyn Inglis, eds.: Handbook on European Enlargement: A Commentary on the Enlargement Process. The Hague: T.M.C. Asser Press, 2002.

Pejanović, Mirko. Politički razvitak Bosne i Hercegovine u postdejtonskom periodu. Sarajevo, 2005. 
---. "Predpostavke za uključivanje BiH u Evropsku Uniju”. Pravna misao.1-2 (januar - februar 1999).

Programski odbor projekta Bosna i Hercegovina Mogućnosti i prespektive razvoja. Bosna i Hercegovina i Euroatlanske Integracije. Sarajevo, 2001.

Richter, Solveig. "The End of an Odyssey in Bosnia and Herzegovina. The Police Reform Smoothes the Way to a Stabilisation and Association Agreement with the EU but Fails to End Stagnation." 10 March 2009

http://www.swp-berlin.org/common/get_document.php?asset_id=5181

EU Road Map. Steps to be taken by Bosnia and Herzegovina to Prepare for a Launch of a Feasibility Study. 08 March 2000. 10 Nov 2008 http://www.esiweb.org/pdf/bridges/bosnia/EURoadMap.pdf.

Sadiković, Lada: Država u evropskom poretku. Sarajevo, 2005.

Sergi, Bruno S. And Qerim R. Qerimi. „The European Union and its prospective enlargement to the south-east. "South-East Europe Review. 4 (2005): 15-32.

Solioz, Christophe. „Europäische Integration und die Verfassungsdebatte in Bosnien und Herzegowina: die Rolle des Europarates." Südosteuropa Mitteilungen 03 (2006): 97-108.

---. "Turning points in post-war Bosnia. Ownership process and European integration." Baden-Baden: Nomos 2007.

Stabilization and Association Agreement between Bosnia and Herzegovina, of the one part, and the European Comunities and their member states, of the other part. 02 Dec 2008. http://www.dei.gov.ba/pdf/SSP-BiH_engleski_glavni_tekst.pdf

The European Union in Bosnia and Herzegovina. Repairing reconstructing reconnecting. European Commission External Relations - DGIA, 1988.

Timmins, Graham and Dejan Jović. „Introduction: The next wave of Enlargement: The European Union and Southeast Europe after 2004." Journal of Southern Europe and the Balkans. Volume 8, Number 1 (April 2006): 1-4.

Topčagić, Osman. Interview. The Adriatic Push for Enlargement. European Stability Initiative. 1 May 2008 http://www.esiweb.org/index.php?lang=en\&id=312.

Treaty on European Union. Official Journal C 191. 29 July 1992. 10 Nov 2008 http://eurlex.europa.eu/en/treaties/dat/11992M/htm/11992M.html\#000100 001

Vanjskotrgovinska Komora Bosne i Hercegovine. Pregled uvoza i izvoza BiH-EU 2000 2007. (Foreign Trade Chamber of Bosnia and Hercegovina. Overview of Import and Export BiH-EU 2000-2007). 01 Dec 2008 
http://komorabih.ba/UserFiles/Image/eu_razmjena.pdf

Zagreb Summit. Final Declaration 24 November 2000. 10 Nov 2008 http://ec.europa.eu/ enlargement/enlargement_process/accession_process/how_does_a_country_join _the_eu/sap/zagreb_summit_en.htm 